\title{
THE OBJECT OF THE CRIME OF HOOLIGANISM
}

\author{
ISMAYILOVA Humay - PhD Candidate of the Azerbaijan National Academy of \\ Aviation
}

DOI:10.32782/NP.2020.1.13

The Criminal Code, as a regulated system of legal norms, performs its warning and educating functions by protecting the social values and public relations established by the Constitution of the Republic of Azerbaijan. The Criminal Code carries out these functions by imposing criminal sanctions (1, p. 21).

According to the first part of Article 63 of the Constitution of the Republic of Azerbaijan, the draft of which was prepared under the leadership of national leader Heydar Aliyev and adopted in a nationwide referendum on November 12, 1995, everyone has the right to the presumption of innocence. Everyone charged with a criminal offense shall be presumed innocent if there is no valid court decision and if his guilt has not been proved in accordance with the law in a public trial (2). It is important to determine the nature of the crime in order to prevent the violation of the rights, freedoms and inviolability of the individual established by the Constitution of the Republic of Azerbaijan.

A crime is a set of objective and subjective features specified in the criminal law, which characterizes a socially dangerous act as a crime. In addition to the elements of the crime, the expression of the elements of the crime is often used in the legal literature. An element of a crime is a structural part of the crime, a group of elements that correspond to different aspects of the act (object, objective aspect, subject, subjective aspect), which is considered a crime by law. The elements of the crime also indicate the elements of the crime.
Criminal law science divides the features of the criminal structure into the following four groups:

a) features characterizing the object of the crime;

b) features characterizing the objective aspect of the crime;

c) features characterizing the subject of the crime;

d) features characterizing the subjective aspect of the crime.

The first two groups of features are called objective features of the crime, and the second two groups of features are called subjective features. The elements of the crime assume a generalized notion of the listed elements, and the sum of these (elements) creates a specific criminal composition (3, pp. 117-118).

Before defining the object of the crime of hooliganism, let's take a general look at the object of the crime. Because in the criminallegal analysis of any norm, including the norm related to hooliganism, in the Special Part of the Criminal Code of the Republic of Azerbaijan, the object of the crime, as an element of the crime, is in the first place. In general, the object of the crime is of special importance in criminal law. That is why the problem of determining the object of a crime has always been in the focus of the theory of criminal law. Firyulin K.A rightly notes that the clarification of the object of the crime allows to determine the social and legal nature of the crime, to reveal its socially dangerous consequences, to answer questions about the scope of the crimi- 
nal law, the definition of the crime and its distinction from similar crimes (4, p. 254).

In the theory of criminal law, the object of the crime is formulated differently. For example, a textbook on the general part of Soviet Criminal Law, published in 1925, states that the object of the crime is public relations protected by the coercive apparatus $(5$, p. 129). These ideas were in line with the Marxist-Leninist teaching.

Indication of public relations as an object of crime was also reflected in the Criminal Code of the Azerbaijan SSR adopted in 1960. Thus, according to Article 7 of the mentioned Code, a socially dangerous act (action or omission), under the criminal law that infringes on the social structure of the USSR, its political and economic system, socialist property, personality, political, labor, property and other rights and freedoms of citizens, as well as other socially dangerous acts violating the rules of socialist law, provided for in the criminal law, was considered a crime.

The Criminal Code of the Republic of Azerbaijan of 30 December 1999 reflected peace and security of mankind, human and civil rights and freedoms, property, economic activity, public order and public safety, environment, as well as the constitutional structure of the Republic of Azerbaijan as the object of the crime (Criminal Code Article 2.1).

According to Zdravomislov B.V the object of the crime is public relations, which are protected by criminal law, which are damaged by crime or can be significantly damaged (6, p. 110). Agayev I.B. giving a similar definition to the object of the crime, shows that the object of the crime is socially significant values, interests and wealth protected by criminal law, intended by the crime and, as a result, harmed or threatened with real harm. The author notes that in the theory of criminal law it is accepted to classify criminal objects on two bases:

- for the degree of generality of socially significant values, interests and wealth protected by law;

- for the importance of the object in the description of a specific crime.

The following objects can be stated according to the degree of generality of socially significant values, interests and wealth protected by law;

- General object of the crime;

- Generic object of the crime

- $\quad$ type of object of the crime;

- the direct object of the crime (7, p. 76).

As can be seen, the study of the concept of the object of the crime, its general and specific features, its place in the system of criminal law categories is of particular importance. We would like to note that the first research on the object of crime in the legal literature dates back to the end of the XVIII century. This was due to the fact that at that time one of the most important categories of criminal law, the criminal component, began to acquire important procedural significance.

The direct object of the crime of hooliganism is public order. Because Article 221 under the title «Hooliganism» of the Criminal Code of the Republic of Azerbaijan, which came into force on September 1, 2000, states: 221.1. "Hooliganism, that is the deliberate actions roughly breaking a social order, expressing obvious disrespect for a society, accompanying with application of violence on citizens or threat of its application, as well as destruction or damage of another's property shall be punished by a fine in the amount of from one thousand manat up to three thousand manat or corrective works for the term up to one year or imprisonment for the term up to one year or imprisonment for the term up to one year.

221.2. The same act:

221.1.1 committed by group of persons or repeatedly;

221.1.2. committed with resistance to representative of the authority, acting as on protection of a social order or stopping infringement of a social order or with resistance to other person shall be punished by corrective works for the term up to two years or restriction of liberty for the term up to three years or imprisonment for the term from one year up to four years.

221.3. "The actions, envisaged in the Articles 221.1 or 221.2 of this Code, committed with application of a weapon or subjects used as the weapon against the victim using force or destruction or damage of another's property 


\section{Кримінальне право, кримінальний процес та криміналістика}

shall be punished by imprisonment for the term from two years up to six years"

It is necessary to state that a public order is a system of rules of conduct and coexistence formed in a society, determined by customs and traditions, moral norms, as well as the current legislation. According to Article 221.1 of the Criminal Code, roughly breaking of social order is an evaluative concept and expresses the importance of the violation. Expressing obvious disrespect for a society has been added to this notion. This feature is considered a necessary element of hooliganism.

Roughly breaking of social order actions are the actions that constitute a prejudicial violation of the rules of coexistence and conduct established between people in society, which cause significant harm to public or private interests. For example, disruption of a cultural, religious or other public event, disturbing the peace of citizens at night, etc. (1, p. 670).

A gross violation of public order, expressed in obvious disrespect for society, is an act of the perpetrator that endangers the normal life and activities of citizens, departments, enterprises and other organizations, and causes fear and anxiety.

Violence should be understood as beatings, damage to health, as well as other acts of violence that physically affect the victim. The threat of violence during hooliganism is the expression of intent to use physical force in words or actions. Liability for a threat arises when there are real grounds for the implementation of this threat.

Destruction of another's property means complete loss of economic and historical value of the property, and damage is the fact that the property does not fully or partially correspond to its purpose, but is damaged to the extent that it can be restored.

The motive for the crime of hooliganism is to prove that the perpetrator is an exceptional person in the minds of an unknown group of people and is fundamentally different from others. The subjective aspect of this crime is a direct conspiracy. The perpetrator realizes that his actions are a gross violation of public order by openly disrespecting the society, and foresees and wishes that as a result of these actions the health of the victim may be harmed or the property of another person may be destroyed or damaged. The absolute condition of the subjective aspect of hooliganism is the motive of this crime. Deliberate attempts to set oneself up against public order, to demonstrate one's power, to incite scandal, and to take revenge on individuals who try to prevent obscenity are the basis of the motive.

The acts of Hooliganism committed by group of persons or repeatedly, committed with resistance to representative of the authority, acting as on protection of a social order or stopping infringement of a social order or with resistance to other person are defined in the Article 221.2 of the Criminal Code.

On March 23, 2004, the Plenum of the Supreme Court of the Republic of Azerbaijan adopted Decision No. 1 "On Judicial Practice in Cases of Hooliganism" consisting of 13 paragraphs. The Preamble of the Decision states: "Article 221 of the Criminal Code of the Republic of Azerbaijan, which came into force on September 1, 2000, provides for liability for hooliganism in a significantly different context than previous Criminal Code. New descriptive features were added to this article, and for the first time, intentional infliction of grievous bodily harm with intent to commit hooliganism was included in the Criminal Code as a descriptive feature of Articles 126.2.4 and 127.2.3, respectively. Legislative innovations, as well as the fact that active actions, which are a necessary feature of the objective aspect of the crime of hooliganism, lead to the commission of a number of other crimes, resulting in an ideal or real set of crimes and thus the emergence of criminal law competition led to the study of the practice of applying the new criminal law on hooliganism by the courts.

Discussing the results of the generalization of judicial practice in cases of hooliganism, the Plenum of the Supreme Court of the Republic of Azerbaijan notes that although substantive and procedural law is generally applied correctly by the courts of the republic, there are serious violations in judicial practice.

The Plenum of the Supreme Court of the Republic of Azerbaijan adopt this Decision in order to establish a unified judicial practice in cases of hooliganism and ensure uniform and correct application of the laws". 
Paragraphs 1-3 of the same decision state: "Courts must take into account that, in accordance with Article 221.1 of the Criminal Code, biased actions of a guilty person grossly violating public order and expressing disrespect to society are punishable only by the use of force against citizens and or under the threat of such coercion, as well as in the event of the destruction or damage of another's property.

Article 296 of the Code of Administrative Offenses of the Republic of Azerbaijan stipulates that the violation of public order and actions that are clearly disrespectful to society are not accompanied by the use or threat of use of force against individuals or the destruction or damage of another's property respectively, leads to administrative liability for petty hooliganism.

It should be explained that in the sense of Article 221 of the Criminal Code, which defines liability for hooliganism, public order means a system of rules of conduct and coexistence established in society by customs and traditions, moral norms, as well as current legislation.

Acts that grossly violate public order are defined as actions that cause significant harm to public or private interests or are intentional violations of the rules of coexistence and behavior established in society.

Obvious disrespect for society means that the perpetrator is clearly indifferent to public order, obviously disregarding the rules of conduct, disregarding the norms of morality and decency, and actions that affect the interests of many people or any member of society.

The courts should draw attention to the need to distinguish hooliganism from other similar crimes. It should be explained that beatings, damage to health, damage to property that occur in a family, in apartment, between relatives, on the basis of personal relations, as well as in a dispute or dispute initiated by the victim, without gross violation of public order and open disrespect for society and other similar acts are not considered hooliganism and, if there are grounds for it, are characterized by relevant articles of the Criminal Code that provide for liability for crimes against the person or for other crimes. "If such actions, initiated on the basis of personal relations, later turn into acts of gross violation of public order and blatant disrespect for society, then the person's actions can be considered hooliganism".

Paragraphs 5 and 6 of the Decision of the Plenum of the Supreme Court of the Republic of Azerbaijan dated March 23, 2004 state: "When distinguishing the crime of hooliganism from the crime of intentional homicide with intent to commit hooliganism, intentional infliction of grievous or less serious harm to health, the courts must take into account that hooliganism is a dangerous act of the perpetrator if the intent to commit hooliganism is manifested as a motive".

Therefore, the actions of a person who has committed the crime of intentional homicide with intent to commit hooliganism, or intentional infliction of grievous bodily harm,respectively must be described in Articles 120.2.2 or 126.2.4 or 127.2.3 of the Criminal Code. In this case, in addition to the commission of any of the above crimes, if it is established that the accused has committed other intentional acts that cause gross violation of public order and open disrespect for society, that person's actions must be described as a cumulative offense under Article 221 of the Criminal Code. It should be explained that as hooliganism committed by resisting a government official or other person who is responsible for maintaining public order or preventing the violation of public order is fully covered by the dispositions of Article 221.2.2 of the Criminal Code, there is no need for additional recommendations with other articles of the Criminal Code.

A government official under Article 221.2.2 of the Criminal Code means all officials who have the authority to prevent violations of public order. Other persons are those who are unauthoritative person obliged to perform public duties or participate in the protection of public order in connection with the performance of a civic duty; Fulfillment of the duty to maintain public order means to carry out post-patrol services on the streets or in public places, demonstrations, pickets, rallies, performances, mass events, the elimination of the consequences of accidents and natural disasters. 


\section{Кримінальне право, кримінальний процес та криміналістика}

Resistance to the use of physical force that does not endanger the life and health of a government official after the cessation of hooliganism (for example, in connection with the arrest of an offender) cannot be considered a descriptive feature of hooliganism and should be described as Articles 221.1 and 315.1 of the Criminal Code as a whole (8).

We consider it necessary to note that the main features of the act of hooliganism are summarized in the criminal law. However, in the works of researchers-investigators and in the practice of investigation and trial, these features have been concretized in some way. It is generally accepted that the direction, activity, and timing of the actions of a person can testify to a gross violation of the public order. It is impossible to disagree with such considerations. However, it should also be taken into consideration that the correct conclusion that this violation does not belong to a gross violation of the public order can only be considered in the analysis of all cases of violation of the law.

Since hooliganism consists of criminal acts with different episodes, not only the nature of the hooligan's behavior, but also the time, place and other circumstances of its commission, the direction of the action against one or more persons, the stubbornness of the hooligan and other features that may be specific to each case, can also have a significant impact on the legal assessment of those actions. All of this suggests that the investigative and judicial authorities must accurately identify and carefully assess all the facts of a gross violation of public order. Such an assessment is based on the requirements of the law, as well as the theoretical provisions put forward by the scientific community of criminal law. Undoubtedly, the concept of law developed in the practice of the investigative-prosecutorial and judicial bodies is not insignificant here.

It should be borne in mind that the nature of hooliganism is largely determined by the properties of the object of the trespass. However, it should not be overlooked that not all of the perpetrators' actions at this time, but some of them, were directed at the public order. In other words, in order to influence the object of the crime under consideration, it is not neces- sary to take arbitrary actions, but only actions that violate the public order in an objective way. For example, such actions as deception of citizens, falsification of documents and so on cannot be assessed as actions that damage the object of hooliganism (9, pp. 63-64).

\section{Bibliographic references}

1. Commentary of the Criminal Code of the Republic of Azerbaijan / edited by Doctor of Law,F.Y.Samandarov, Baku, Digesta,2012, 1104 p. [In Azerbaijani].

2. The Constitution of the Republic of Azerbaijan. Baku: "Law Publishing House", 2017, 92 p. [In Azerbaijani].

3. Samandarov F.Y. Criminal law: General part. Textbook. Baku: Digesta, 2013, 720 p. [In Azerbaijani].

4. Firyulin K.A. The historical development of the concept of the object of crime and the need for its clarification / Bulletin of the Law Institute of the Chuvash State University named after I.N. Ulyanova. The collection of materials of the scientific-practical conference dedicated to the fifteenth anniversary of the law faculty of Chuvash State University. Cheboksary: Publishing House of the Chuvash State University, 2007, No. 1 (19), p. 254-259 [in Russian].

5. Piontkovsky A.A. The criminal law of the RSFSR. General part. Moscow: State publishing house, 1925, 235 p. [in Russian].

6. Criminal law of the Russian Federation: General part. Textbook / Res. ed. B.V.Zdravomislov. Moscow: Yurist, 1996, 512 p. [in Russian].

7. Ağayev İ.B. Criminal law of the Republic of Azerbaijan: general and special parts. Textbook. Baku: Nurlar, 2010, 832 p. [In Azerbaijani].

8. Decision No. 1 of the Plenum of the Supreme Court of the Republic of Azerbaijan dated March 23, 2004 "On Judicial Practice in Cases of Hooliganism" http:/e-qanun.az/ alpidata/framework/data/16/f_16737.htm [In Azerbaijani].

9. Sadikhov R.A Criminal-legal fight against hooliganism. Baku, 2013, 183 p. [In Azerbaijani]. 
Исмаилова Гюмай Алтай къззи докторант Национальной Академии Авиачии Азербайджана ОБЪЕКТ ПРЕСТУПАЕНИЯ ХУАИГАНСТВА

В статье указывается, что определение непосредственного основного объекта хулиганства как общественного порядка естественно вытекает из диспозиции статьи 221 Уголовного кодекса Азербайджанской Республики, в которой нарушение общественного порядка выступает центральным звеном уголовной ответственности

Ключевые слова: Кодекс, право, статья, уголовный, здоровье.

\section{SUMMARY}

The article states that the definition of the immediate main object of hooliganism as public order naturally follows from the disposition of article 221 of the Criminal Code of the Republic of Azerbaijan, in which violation of public order is the central link of criminal responsibility.

Key words: Code, law, article, criminal, health, 